\title{
Antibacterial and Antifungal Approaches of Ficus racemosa
}

\author{
Tanvi Pingale ${ }^{1, *}$, Pallavi Duse ${ }^{2}$, Sunita Ogale ${ }^{3}$
}

\section{Tanvi Pingale ${ }^{1 *}$, Pallavi Duse ${ }^{2}$, Sunita Ogale $^{3}$}

${ }^{1}$ Assistant Professor in Pharmacology, VIVA Institute of Pharmacy, Virar, Maharashtra, INDIA.

${ }^{2}$ Assistant Professor in Quality Assurance, VIVA Institute of Pharmacy, Virar, Maharashtra, INDIA.

${ }^{3}$ VIVA Institute of Pharmacy, Virar, Maharashtra, INDIA.

\section{Correspondence}

Prof. Tanvi Pingale

Assistant Professor in Pharmacology, VIVA Institute of Pharmacy, Virar, Maharashtra, INDIA.

Phone no : 9960102418

E-mail: tanvi.pingale@gmail.com

\section{History}

- Submission Date: 26-11-2018;

- Review completed:13-12-2018;

- Accepted Date: 29-12-2018

DOI : 10.5530/pj.2019.11.53

Article Available online

http://www.phcogj.com/v11/i2

\section{Copyright}

(C) 2019 Phcog.Net. This is an openaccess article distributed under the terms of the Creative Commons Attribution 4.0 International license.

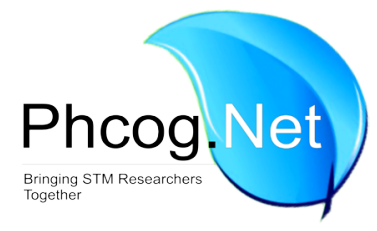

\begin{abstract}
Ficus racemosa also called as Ficus glomerata Roxb. is a species of plant in the family Moraceae. Popularly known as the Audumbar, cluster fig tree, Indian fig tree or goolar (gular). Different parts of plant shows Antibacterial, Antitussive, Anthelmintic, Antidiarrhoeal, Anticancer, Anti-inflammatory activities etc. on various extracts. Latest and previous studies have concluded the beneficial aspects of fruit of the plant shows Antimicrobial, Antibacterial and Antifungal activity using different cultures and extracts. Materials and Methods: The method was adopted for preparation of plant extracts. The media used for antibacterial test was Nutrient agar/broth. The culture medium was inoculated with the microorganism separately suspended in nutrient broth. The antibacterial activity was evaluated by measuring the diameter of zone of inhibition observed. The broth dilution method was adopted for determination of $\mathrm{MIC}$ value against the pathogens. Results and Discussion: The ethanoic and ethyl acetate extract showed more promising antimicrobial activity as compared to Water, Hexane and Chloroform extract. In well diffusion method, the ethyl acetate extract had showed significant bactericidal activity.

Key words: Ficus racemosa, Moraceae, Soyabean casein digest agar, Anthraquinone glycosides.
\end{abstract}

\section{INTRODUCTION}

Ficus racemose popularly known as the Audumbar, cluster fig tree, Indian fig tree or goolar (gular) which is also called as Ficus glomerata Roxb, is a plant species belongs the family Moraceae. In India, the tree fruits are called gular. Gluanol acetate was the major component of fruits. The other components were lupeol acetate, friedelin, glucanol, tiglic acid, taraxasterol and hydrocarbons. ${ }^{1}$ The leaves the plant is rich in triterpenoids (basically lanosterol), flavonoids, alkaloids and tannins. Gluanol acetate and racemosic acid are the new triterpenes. ${ }^{2}$ The bark of tree is said to have healing power. The major component of the stem bark was Bergenin which is a flavonoid. The other major components of the stem bark were glycosides sterols $(\beta$-sitosterol, stigmasterol, $\alpha$-amyrin acetate, lupeol and lupeol acetate), (leucocyanidin-3-O- $\beta$-D-glucopyrancoside, leucopelargonidin-3-O- $\beta$-D-glucopyranoside, leucopelargonidin-3-O- $\beta$-D-glucopyranoside and leucopelargonidin-3-O- $\alpha$-L-rhamnopyranoside); and tannins (ellagic acid). ${ }^{3}$ The trunk bark contains various types of sterols like $\beta$-sitosterol, lupenol and stigmasterol. ${ }^{2}$ The latex rich in various types of steroids such as isoeuphorbol, $\beta$-sitosterol, euphol, 4-deoxyphorbol, cycloartenol and cycloeuphordenol. ${ }^{1}$

Different parts of Ficus racemose shows Antibacterial, Hepatoprotective, Antitussive, Antiulcer, Wound healing, Anthelmintic, Antidiuretic effect, Antidiarrheal, Chemo preventive effect on the nephron, Anticancer, Antiinflammatory activities etc. on various extracts. ${ }^{4}$ Antibacterial means anything to destroy bacteria or suppresses their growth. ${ }^{5}$ Antimicrobial activity is the process of inhibiting or killing the disease caused due to microbes while Antifungal activity is destroy fungi or inhibiting fungal growth. ${ }^{6}$ Latest and previous studies have concluded the beneficial aspects of fruit of the plant shows Antimicrobial, Antibacterial and Antifungal activity using different cultures comparing various extracts. ${ }^{7-8}$

\section{MATERIALS AND METHODS}

\section{Experimental Section}

All the chemicals and reagents used were from Bhavichem.

The media and broth used for microbial culture were from Hi-Media Pvt. Limited, Bombay, India.

\section{Plant material}

The authenticated sample was collected from local market of Mumbai

\section{Preparation of plant extracts}

The method was adopted for preparation of plant extracts with little modifications. Briefly

Five $10 \mathrm{~g}$ portions of each of the powdered plant material of the fruit of the tree were soaked separately in $100 \mathrm{ml}$ of water, chloroform, ethyl acetate, hexane and ethanol for $72 \mathrm{~h}$. Each mixture was stirred after every $12 \mathrm{~h}$ using a sterile glass rod. At the end of extraction, each extract was passed through Whatmann filter paper no1. ${ }^{9}$ 


\section{Determination of Antibacterial and Antifungal Activity} Culture Media

The media used for antibacterial test was Nutrient agar/broth.

\section{Inoculum}

The bacteria were inoculated into soyabean casein digest agar/broth and incubated at $37^{\circ} \mathrm{C}$ for $4 \mathrm{~h}$ and the suspension were checked to provide approximately $105 \mathrm{CFU} / \mathrm{ml}$.

\section{Microorganisms used}

The bacterial test organisms E. coli, Klebsiella pneumoniae, Streptococcus aureus and Salmonella typhi and the fungal test organisms used for study were Candida albicans and Aspergillus niger.

\section{Determination of antimicrobial activity}

The agar well diffusion method was modified. Nutrient agar medium was used for bacterial cultures. The culture medium was inoculated with the microorganism separately suspended in nutrient broth. A total of $8 \mathrm{~mm}$ diameter wells were punched into the agar and filled with plant extracts $(1 \mathrm{mg} / \mathrm{ml})$ and solvent blank (hydro-alcohol as the case may be). Standard antibiotic Chloramphenicol (concentration $1 \mathrm{mg} / \mathrm{ml}$ ) was simultaneously used as positive control. The bacterial plates were then incubated at $37^{\circ} \mathrm{C}$ for $24 \mathrm{~h}$. The antibacterial activity was evaluated by measuring the diameter of zone of inhibition observed. The same procedure was done for determining antifungal activity but in this case standard antibiotic (Ketokonazole, concentration $1 \mathrm{mg} / \mathrm{ml}$ ) was used as positive control and fungal plates were incubated at $37^{\circ} \mathrm{C}$ for $72 \mathrm{~h}$. Here also the diameter of zone of inhibition observed was measured..$^{10}$

\section{Determination of MIC}

The broth dilution method was adopted for determination of MIC value against the pathogens. The plant extracts $(1 \mathrm{mg} / \mathrm{ml})$ were serially diluted in different aliquots and the final volumes of the aliquots were made up to $1 \mathrm{ml}$ with $\mathrm{N}$-saline $(0.85 \% \mathrm{NaCl})$. Equal amount of the specific pathogen were added in different aliquots and the test tubes were kept for $48 \mathrm{~h}$ at $300^{\circ} \mathrm{C}$. The minimum dilution of the plant extract that kills the bacterial and fungal growth was taken as

MLC (Minimum lethal count) while the minimum dilution of plant extract that inhibits the growth of the organism was taken as MIC. ${ }^{11}$

\section{Phytochemical screening of the different parts of the tree}

Different conventional methods were followed to determine qualitatively the presence of phytochemical constituents present in the extract. ${ }^{12}$

\section{RESULTS}

Phytochemical tests for the presence of active metabolites in the ficus recemosa fruits.

All extractive were negative for alkaloid and anthraquinone glycosides.

\section{Determination of antimicrobial activity}

Antimicrobial activity MIC concentration (mg/ml) (Table 3)

\section{DISCUSSION}

The dried fruits extracts of ficus racemose was obtained by maceration method. The yield of water, choroform, ethyl acetate, hexane and ethanol extracts was found to be $9.18 \mathrm{w} / \mathrm{w}, 1.82 \mathrm{w} / \mathrm{w}, 12.98 \mathrm{w} / \mathrm{w}, 1.09 \mathrm{w} / \mathrm{w}$ and $5.23 \mathrm{w} / \mathrm{w}$ repectively.

Table 1: Extractive Value.
\begin{tabular}{cccccc} 
solvents & water & chloroform & $\begin{array}{c}\text { Ethyl } \\
\text { acetate }\end{array}$ & Hexane & Ethanol \\
\hline $\begin{array}{c}\text { Extractive } \\
\text { value }\end{array}$ & $9.18 \mathrm{w} / \mathrm{w}$ & $1.82 \mathrm{w} / \mathrm{w}$ & $12.98 \mathrm{w} / \mathrm{w}$ & $1.09 \mathrm{w} / \mathrm{w}$ & $5.23 \mathrm{w} / \mathrm{w}$ \\
Colour & Brownish & Brownish & Brownish & Greenish & Brownish \\
\hline
\end{tabular}

* Each value is an average of three determinations.

Table 2: Phytochemical tests.

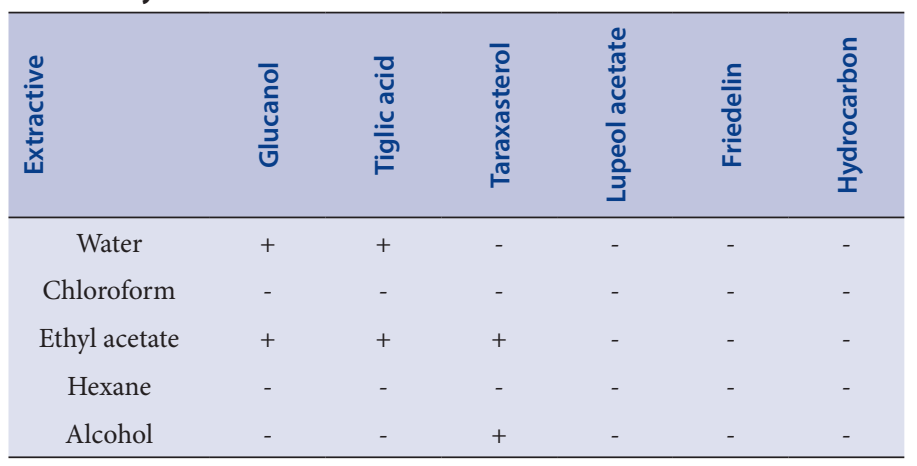

Table 3: Antimicrobial activity MIC concentration ( $\mathrm{mg} / \mathrm{ml})$.

\begin{tabular}{cccccc}
\hline Organism & \multicolumn{5}{c}{ MIC Conc. Mg/ml } \\
\cline { 2 - 6 } & Water & Alcohol & Hexane & Chloroform & $\begin{array}{c}\text { Ethyl } \\
\text { acetate }\end{array}$ \\
\hline E. coli & 3.12 & 1.56 & 6.16 & 6.25 & 1.32 \\
S. aureus & 6.25 & 3.12 & 4.28 & 3.12 & 0.98 \\
S. typhi & 3.12 & 1.56 & 5.32 & 6.25 & 1.76 \\
K. pnem. & 2.78 & 1.56 & 6.49 & 3.12 & 1.52 \\
A. niger & 1.24 & 1.68 & 5.69 & 4.32 & 1.39 \\
C. albicans & 1.56 & 0.78 & 6.56 & 3.12 & 2.19 \\
\hline
\end{tabular}

The preliminary phytochemical analysis of extracts have showed the presence of Glucanol, Tiglic acid, Taraxasterol, Lupeol acetate, Friedelin, Hydrocarbon, in addition to this they showed the presence of carbohydrate and mucilage.

The Water, Ethanol, Hexane, Chloroform and Ethyl acetate extracts of Ficus racemosa were subjected to in vitro antimicrobial studies by well diffusion method.

The ethanolic and ethyl acetate extract showed more promising antimicrobial activity as compared to Water, Hexane and Chloroform extract.

In well diffusion method, the ethyl acetate extract had showed significant bactericidal activity against E.coli, S. aureus, S. typhi, K. pnem at concentration $1.32 \mathrm{mg} / \mathrm{ml}, 0.98 \mathrm{mg} / \mathrm{ml}, 1.76 \mathrm{mg} / \mathrm{ml}, 1.52 \mathrm{mg} / \mathrm{ml}$ respectively and fungistatic against Aspergillus niger and $C$. albicans at concentration $1.39 \mathrm{mg} / \mathrm{ml}$ and $2.19 \mathrm{mg} / \mathrm{ml}$ respectively in Table (3).

\section{CONCLUSION}

The minimum inhibitory concentration of combined extract was found to be $1 \mathrm{mg} / \mathrm{ml}$.

The antimicrobial activity of water, choroform, ethyl acetate, hexane and ethanol extracts of Ficus racemosa L was probably due to of some important secondary metabolites observed in preliminary phytochemical tests. 
Therefore, this property of chemical component in these herbs can be used to discover natural bioactive products that potentially enhance the therapeutic value in the development of novel pharmaceutical research activities and suggesting for using potential antibacterial agents to cure bacterial infection.

\section{ACKNOWLEDGEMENT}

Firstly, we are thankful to our Principal Dr. Sunita Ogale from VIVA Institute of Pharmacy, Virar to motivate and helping us for conducting this study. We are also thankful to Bhavichem for providing us Laboratory chemicals and reagents. We are also acknowledge to Hi-Media Pvt. Limited, Bombay, India for providing the media and broth used for microbial culture.

\section{CONFLICT OF INTEREST}

The authors declare no conflict of interest.

\section{ABBREVIATIONS}

MLC: Minimum Lethal Count; MIC: Minimum Inhibitory Concentration; CFU: Colony Forming Unit

\section{REFERENCES}

1. Abhishek M, Gautam K, Singh, Satish K, Verma, SajadY, et al. Dua4 Phytochemical investigation and in vitro antimicrobial activity of different parts of Ficus racemosa L. Pelagia Research Library, Der Pharmacia Sinica. 2011;2(2):270-5.

2. Ahmed F, Chandra JN, Manjunath S. Acetylcholine and memory enhancing activity of Ficus racemosa bark. Pharmacognosy Res. 2011;3(4):246-9.

3. Biswas TK, Mukherjee B. Plant medicines of Indian origin for wound healing activity: a review. Int J Low Extreme Wounds. 2003;2(1):25-39.

4. Perez C, Anesini C. J Ethnopharmacol. 1993:44:41-6.

5. Chandrashekhar $\mathrm{CH}$, Latha KP, Vagdevi HM, Vaidya VP. Anthelmintic activity of the crude extracts of Ficus racemosa. Int J Green Pharm. 2008;2(2):100-3.

6. Trease GE, Evans WC. Pharmacogonasy, 1989, Brown Publication, $14^{\text {th }}$ Edition.

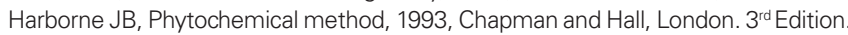
135-203.

7. Joseph B, Raj SJ. Phytopharmacological and phytochemical properties of three ficus species-an overview. Int J Pharma Bio Sci. 2010;1(4):246-53.

8. Li RW, Leach DN, Myers SP, Lin GD, Leach GJ, Waterman PG. A new antiinflammatory glucoside from Ficus racemosa. Planta Med. 2004;70(05):421-6.

9. Mandal SC, Maity TK, Das J, Pal M, Saha BP. Hepatoprotective activity of Ficus racemosa leaf extract on liver damage caused by carbon tetrachloride in rats. Phytother Res. 1999;13(5):430-2.

10. Mandal SC, Maity TK, Das J, Saha BP, Pal M. Anti-inflamatory evaluation of Ficus racemosa Linn. leaf extract. J Ethanopharmacol. 2000;72(1-2):87-92.

11. Alade PI, Irobi ON. J Ethnopharmacol. 1993;39:171-4.

12. Rao $\mathrm{CHV}$, Verma AR, Vijay KM, Rastogi S. Gastric protective effect of standardized extract of Ficus glomerata fruit on experimental gastric ulcers in rats. J Ethnopharmacol. 2008;115(2):323-6

13. Shiksharthi AR, Mittal S. Ficus racemosa: Phytochemistry, traditional uses and pharmacological properties: A review. Int J Adv Pharm Res. 2011;4:6-15.

\section{GRAPHICAL ABSTRACT}

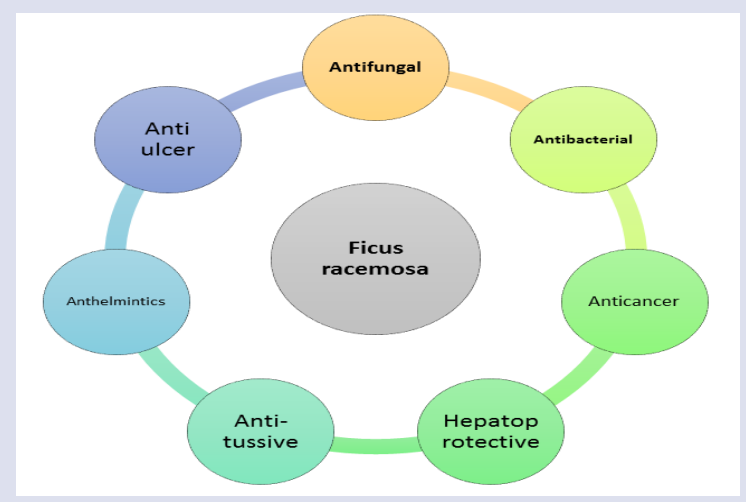

\section{SUMMARY}

- Ficus racemosa also called as Audumbar is a species of plant in the family Moraceae. This plant have various activities. Different part of plant shows different activity. In this article proves antibacterial activity of Ficus racemose using ethanolic and ethyl acetate extract. Therefore, this property of chemical component can be used to enhance the therapeutic value in the development of novel pharmaceutical research activities and suggesting for using potential antibacterial agents to cure bacterial infection.

\section{ABOUT AUTHORS}

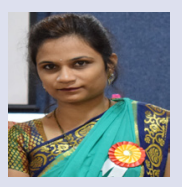

Pallavi Duse: is an Assistant Professor in VIVA institute of Pharmacy, M. pharm in Quality Assurance Specialization Area: Analytical Techniques. Master of Pharmacy, Specialization in Quality Assurance at Y.B. Chavan College of Pharmacy, Aurangabad, India. Worked at Midas-Care Pharmaceuticals Aurangabad in Quality Assurance Department. Currently working as an Assistant Professor in VIVA Institute of Pharmacy, Virar.

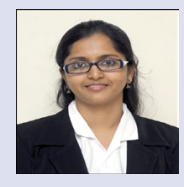

Tanvi Pingale, is an Assistant Professor in VIVA institute of Pharmacy, M. pharm in Pharmacology, Specialization Area: CNS Currently working with VIVA Institute of Pharmacy since July - 2016 having work experience of 2 years and designated as an Assistant Professor (Degree) in subjects of Pharmacology, Anatomy Physiology and Pathophysiology Theory and Laboratory and Hospital Pharmacy and Drug Store Management Theory. In June 2015 to July 2016 worked in NSS College of Pharmacy, Tardeo, Mumbai (Diploma) as a lecturer in subjects of Hospital and Clinical Pharmacy, Anatomy and Physiology and Pharmacology Theory and Laboratory.

Cite this article: PingaleT, Duse P, Ogale S. Antibacterial and Antifungal Approaches of Ficus racemosa. Pharmacog J. 2019;11 (2):3557. 